\title{
GERMINATION TEMPERATURES AFFECT THE PHYSIOLOGICAL QUALITY OF SEEDS OF LETTUCE CULTIVARS
}

\author{
QUALIDADE FISIOLÓGICA DE SEMENTES DE ALFACE SOB DIFERENTES \\ TEMPERATURAS NA GERMINAÇÃO
}

\section{Fernando Araujo de ALMEIDA'; Renata SILVA-MANN; Heloisa Oliveira dos SANTOS²; Rucyan Walace PEREIRA ${ }^{2}$; Arie Fitzgerald BLANK ${ }^{1}$}

1. Universidade Federal de Sergipe-UFS, São Cristóvão, SE, Brasil. renatamann @ gmail.com; 2. Universidade Federal de Lavras/UFLA, Lavras, MG, Brasil.

\begin{abstract}
The objective of this study was to evaluate the physiological quality allied to biochemical quality of lettuce seeds by germination and enzymes expression at $20,25,30,35,40$ and $42^{\circ} \mathrm{C}$. Germination speed index and percentage of germination were estimated. Isoenzyme expressions were assessed by alcohol dehydrogenase (ADH), malate dehydrogenase (MDH), catalase (CAT), esterase (EST), pyruvate decarboxylase (PDC) and glutamate oxaloacetate transferase (GOT). The experiment consisted of a completely randomized design in a factorial scheme $4 \times 6$, with four cultivars and six different temperatures, with four replications. The highest germination and vigor were observed for cv. 'Everglades' at $35^{\circ} \mathrm{C}$, which proved that this cultivar is thermotolerant. Catalase can be considered a genetic marker for the identification of thermotolerant lettuce cultivars. Cultivar 'Everglades' has potential to be used in lettuce breeding programs aimed at cultivars tolerant to high temperatures during germination.
\end{abstract}

KEYWORDS: Lactuca sativa L. Isoenzymes. Thermotolerance. Esterase. Catalase. Alcohol dehydrogenase.

\section{INTRODUCTION}

Lettuce (Lactuca sativa L.) is a species of high economic value, and has been appreciated by the world's population, usually as salads and in sandwiches.

Lettuce production has become easier in several regions due to the modernization of agriculture; however, there are still strong limitations. Most of the commercialized cultivars is sensitive to heat, which results in the emission of early flower stem.

Seeds of most lettuce cultivars are susceptible to thermoinhibition, or failure to germinate at temperatures above approximately $28^{\circ} \mathrm{C}$, creating problems for crop establishment in the field. Identifying genes controlling thermoinhibition would enable the development of cultivars lacking this trait and, therefore, being less sensitive to high temperatures during planting (YOONG et al., 2016).

In general, temperatures above $30^{\circ} \mathrm{C}$ affect the germination and trigger seed dormancy. Thus, since high temperatures all over the year is predominant in most regions of Brazil, germination of lettuce seeds can be reduced, which consequently affects stand field.
The impairment of lettuce seeds during germination may occur under conditions of high temperatures by thermoinhibition, which is a reversible process, i.e., at the reduced temperature. On the other hand, complete inhibition of germination may also occur, which is denominated thermodormancy (KOZAREWA et al., 2006).

Everglades were used to evaluate the performance of pelleted and bare seeds of lettuce under different germination temperatures at 17 to $19^{\circ} \mathrm{C}, 21$ to $23^{\circ} \mathrm{C}, 25$ to $28^{\circ} \mathrm{C}, 30$ to $32^{\circ} \mathrm{C}, 34$ to $38^{\circ} \mathrm{C}$. The cultivar Everglades showed a higher germination, especially with pelleted seeds (ZUFFO et al., 2017).

The mechanism of action for lettuce seeds germination at high temperatures seems to be related to the weakening of the endosperm, which allows the embryo to grow at elevated temperatures. The first hours of imbibition are critical for germination under high temperature conditions, since the embryo is fully included in the endosperm, where the radicle must penetrate to grow and complete the germination process (NASCIMENTO, 2003; NASCIMENTO et al., 2004).

The endosperm is the main tissue that prevents embryo growth in lettuce seeds, and for germination it is necessary that the embryo breaks the physical barriers that surround it (SUNG et al., 
2008). The activity of enzymes weakens the cell walls that surround the embryo, making possible their development (CATÃO, 2014). Therefore, it is important to analyze the enzymes related to lettuce seed germination under optimum and critical temperature, and to observe differences in electrophoretic profiles that may assist in identifying thermotolerant genotypes.

The seed physiology in lettuce seeds can be evaluated using isoenzymes submitted to different conditions and storage periods. The lettuce cultivar Everglades, Babá de Verão, Elisa, Grand Rapids were tested under four storage periods $(30,60,90$ and 120 days), on three storage rooms $(15,25$ and $35^{\circ} \mathrm{C}$ ). The physiological quality was evaluated by first and final germination count, emergence, and germination and emergence speed indexes. The isoenzyme expression of catalase (CAT), esterase (EST), alcohol dehydrogenase (ADH) and malate dehydrogenase (MDH). The high room temperatures associated with higher storage periods cause a reduction in physiological quality and alterations in enzymatic patterns of CAT, EST, ADH and MDH. The lettuce cultivars, especially Everglades, have different levels of tolerance to storage and isozyme expressions (CATÃO et al., 2016).

The aim of this study was to evaluate the physiological quality and the differences in the biochemical activity of enzymes of lettuce seeds germinated under stress of different temperatures.

\section{MATERIAL AND METHODS}

The cultivars tested were 'Babá de Verão' (white seeds), 'Elisa', 'Grand Rapids' (black seeds) and 'Everglades' (black seeds); the latter was determined as thermotolerant (NASCIMENTO et al., 2001; KOZAREWA et al., 2006; CATÃO et al., 2014). Although they are cultivars that are basically no longer planted, they are still as source of germplasm for crosses in lettuce breeding programs.

Seeds were produced in a protected environment (Ijaci City - latitude 21 ${ }^{\circ}$ '24'S, longitude $44^{\circ} 55^{\prime} 34^{\prime \prime} \mathrm{W}$, altitude of $889 \mathrm{~m}$ ) Minas Gerais, during the summer of 2015. After harvesting, seeds were dried until they reached $8 \%$ water content and storage at cold chamber.

The evaluation of physiological and biochemistry quality was initially carried out in order to verify the water content determined at $105^{\circ} \mathrm{C}$ for 24 hours (BRASIL, 2009).

\section{Determination of water content}

It was performed before the beginning of the tests the determination of water content in air circulation oven method at $105^{\circ} \mathrm{C}$ for 24 hours, accordance with the Rules for the Seeds (Brazil, 2009). The results were expressed as percentage.

\section{Speed and percentage of germination}

Eight replicates of 25 seeds for each cultivar were placed on the in transparent plastic boxes $(11 \mathrm{x}$ $11 \times 3 \mathrm{~cm}$ ), on two sheets bellow and one above blotting paper and moistened with an amount of water equivalent to 2.5 times the mass of the dried substrate. At boxes with the seeds were placed in a germination chamber type BOD under alternated light every $12 \mathrm{~h}$, at $20,25,30,35,40$ and $42^{\circ} \mathrm{C}$. Germination was evaluated on the fourth and seventh days, computing the average number of seedlings following established criteria in the Rules for Seed Analysis (Brazil, 2009). The speed index of germination was calculated according to expression proposed by Maguire (1962). The percentage of germination was calculated according to the number of normal seedlings obtained seven days after test installation.

\section{Enzymes analysis}

For the analysis of the enzymes alcohol dehydrogenase, malate dehydrogenase, catalase, esterase, pyruvate decarboxylase and glutamate oxalacetate transferase were extracted using $250 \mathrm{~mL}$ of extraction buffer (Tris- $\mathrm{HCl} 0.2 \mathrm{M} \mathrm{pH} \mathrm{8;0.1 \%} \beta$ mercaptoethanol) in $100 \mathrm{mg}$ macerated seeds. Fifty $\mathrm{mL}$ aliquots for each sample were carried out by electrophoresis in polyacrylamide gels with buffer/electrode system of Tris-glycine, $\mathrm{pH}$ 8.9. The enzyme profile was revealed by specific substrates (ALFENAS, 2006).

Differences in enzymes profiles were analyzed for each band allele density by pixels, using the software ImageJ (RASBAND, 2016).

Germination data were previously subjected to normality tests and homoscedasticity of variance, followed by ANOVA, and means were compared by the Tukey test at $5 \%$ probability (FERREIRA, 2011).

\section{RESULTS AND DISCUSSION}

The moisture content of the seeds ranged from 5.2 to $6.3 \%$, as described by Barbosa et al. (2011) and Catão et al. (2014), using different lots of lettuce seeds.

There were significant differences among cultivars germinated at different temperatures $(\mathrm{p}<0.05)$ (TABELA 1).

At $20^{\circ} \mathrm{C}, 70 \%$ of normal seedlings were observed for all cultivars. At $25^{\circ} \mathrm{C}$, less than $70 \%$ 
germination was observed only for cultivar 'Babá de Verão'. At $30^{\circ} \mathrm{C}$ and $35^{\circ} \mathrm{C}$, there was variation of germination percentage for 'Everglades', which is considered a thermotolerant cultivar under high temperatures (KOZAREWA et al., 2006; CATÃO et al., 2014). There was no germination for all cultivars for temperatures above $40^{\circ} \mathrm{C}$, which was also reported by other authors (NASCIMENTO et al., 2012), who observed null germination for most lettuce genotypes in temperatures above $30^{\circ} \mathrm{C}$.

For all cultivars, germination percentage decreased from $20^{\circ} \mathrm{C}$ to $35^{\circ} \mathrm{C}$, with reduction of 29\% for 'Everglades', $81 \%$ for 'Grand Rapids',
$74 \%$ for 'Elisa', and $73 \%$ for 'Babá de Verão'. Raises of temperature affected the quality of seeds; however, it affected on a small-scale for 'Everglades'. Vigor tests assist in the distinction between seeds with germination defined by commercial standards (KIKUTI \& MARCOS FILHO, 2012). 'Everglades' and 'Elisa' achieved values of germination above the average commercial standard at the fourth day of evaluation. However, at $25^{\circ} \mathrm{C}$, higher vigor was observed only for 'Everglades'. Intermediate germination rate was observed for 'Elisa' and 'Babá de Verão', followed by 'Grand Rapids', which presented low vigor.

Table 1. Germination (\%) at the seventh day, first count (\%), germination (\%) at the eleventh day, germination speed, and germination speed index for lettuce cultivars (Lactuca sativa $\mathrm{L}$.

\begin{tabular}{|c|c|c|c|c|}
\hline \multirow[t]{2}{*}{ Cultivar } & \multicolumn{4}{|c|}{ Temperature $\left({ }^{\circ} \mathrm{C}\right)$} \\
\hline & 20 & 25 & 30 & 35 \\
\hline \multicolumn{5}{|c|}{ Germination (\%) at the seventh day } \\
\hline Everglades & $100 \mathrm{Aa}$ & $100 \mathrm{Aa}$ & 94 Аа & $71 \mathrm{Ab}$ \\
\hline Grand Rapids & $83 \mathrm{Ba}$ & $80 \mathrm{Ba}$ & $55 \mathrm{Bb}$ & $2 \mathrm{Cc}$ \\
\hline Elisa & $80 \mathrm{Ba}$ & $75 \mathrm{Ba}$ & $7 \mathrm{Cb}$ & $6 \mathrm{Bb}$ \\
\hline Babá de Verão & $77 \mathrm{Ba}$ & $65 \mathrm{Cb}$ & $7 \mathrm{Cc}$ & $4 \mathrm{Bc}$ \\
\hline $\mathrm{CV}(\%)$ & & & & \\
\hline \multicolumn{5}{|c|}{ First count of germination (\%) at the fourth day } \\
\hline Everglades & $99 \mathrm{Aa}$ & $87 \mathrm{Aa}$ & $92 \mathrm{Aa}$ & $10 \mathrm{Ab}$ \\
\hline Grand Rapids & $12 \mathrm{Cc}$ & $42 \mathrm{Ca}$ & $29 \mathrm{Bb}$ & $0 \mathrm{Ac}$ \\
\hline Elisa & $76 \mathrm{Ba}$ & $63 \mathrm{Bb}$ & $5 \mathrm{Cc}$ & $0 \mathrm{Ac}$ \\
\hline Babá de Verão & $66 \mathrm{Ba}$ & $57 \mathrm{Ba}$ & $6 \mathrm{Cb}$ & $0 \mathrm{Ab}$ \\
\hline CV (\%) & & & & \\
\hline \multicolumn{5}{|c|}{$\begin{array}{c}22.72 \\
\text { Germination (\%) at the elenventh day }\end{array}$} \\
\hline Everglades & $100 \mathrm{Aa}$ & $100 \mathrm{Aa}$ & $94 \mathrm{Aa}$ & $33 \mathrm{Ab}$ \\
\hline Grand Rapids & $81 \mathrm{Ba}$ & $81 \mathrm{Ba}$ & $64 \mathrm{Bb}$ & $2 \mathrm{Bc}$ \\
\hline Elisa & $82 \mathrm{Ba}$ & $76 \mathrm{Ba}$ & $8 \mathrm{Cb}$ & $6 \mathrm{Bb}$ \\
\hline Babá de Verão & $78 \mathrm{Ba}$ & $66 \mathrm{Cb}$ & $8 \mathrm{Cc}$ & $4 \mathrm{Bc}$ \\
\hline $\mathrm{CV}(\%)$ & & & & \\
\hline \multicolumn{5}{|c|}{ Germination (day) } \\
\hline Everglades & $4 \mathrm{Aa}$ & $4 \mathrm{Aa}$ & $4 \mathrm{Aa}$ & $5 \mathrm{Aa}$ \\
\hline Grand Rapids & $5 \mathrm{Ba}$ & $5 \mathrm{Ba}$ & $6 \mathrm{Ca}$ & $9 \mathrm{Cb}$ \\
\hline Elisa & $4 \mathrm{Aa}$ & $5 \mathrm{Ba}$ & $5 \mathrm{Ba}$ & $7 \mathrm{Bb}$ \\
\hline Babá de Verão & $4 \mathrm{Aa}$ & $5 \mathrm{Ba}$ & $5 \mathrm{Ba}$ & $8 \mathrm{Bb}$ \\
\hline $\mathrm{CV}(\%)$ & & & & \\
\hline \multicolumn{5}{|c|}{ Germination Speed Index (GSI) } \\
\hline Everglades & $12.16 \mathrm{Aa}$ & $11.42 \mathrm{Aa}$ & $10.33 \mathrm{Aa}$ & $3.35 \mathrm{Ab}$ \\
\hline Grand Rapids & $6.70 \mathrm{Ca}$ & $5.41 \mathrm{Cb}$ & $4.13 \mathrm{Cc}$ & $2.09 \mathrm{Cd}$ \\
\hline Elisa & $9.54 \mathrm{Ba}$ & $8.76 \mathrm{Ba}$ & $6.49 \mathrm{Bb}$ & $3.11 \mathrm{Bc}$ \\
\hline Babá de Verão & $9.76 \mathrm{Ba}$ & $8.87 \mathrm{Bb}$ & $6.61 \mathrm{Bc}$ & $3.03 \mathrm{Bd}$ \\
\hline $\mathrm{CV}(\%)$ & & & & \\
\hline
\end{tabular}

Means followed by the same lowercase letter in the rows, and by the same uppercase letters in the columns do not differ by the Tukey test at $5 \%$ probability.

The performance of 'Everglades' at $30^{\circ} \mathrm{C}$ was maintained above the minimum established for commercial germination standard. Therefore, this cultivar can be used as control for the determination of the value for cultivation and use, when compared with other genotypes. Emission of radicule for 'Elisa' and 'Babá de Verão' was observed for germination on the seventh day. 
Reduction rate in germination occurs after increases of $5^{\circ} \mathrm{C}$ from $20^{\circ} \mathrm{C}$ and $25^{\circ} \mathrm{C}$, except for 'Everglades' and 'Grand Rapids'. According to Nascimento (2003), the optimum temperature to achieve normal lettuce seedlings is approximately $20^{\circ} \mathrm{C}$.

However, when comparing the germination of 'Elisa' and 'Babá de Verão' on the seventh and eleventh day, germination increased at $20^{\circ} \mathrm{C}, 25^{\circ} \mathrm{C}$ and $30^{\circ} \mathrm{C}$, which shows that these cultivars could germinate, which may result in uniformity of seedling establishment.

These results evidence that the evaluation of the germination on the eleventh day did not result in germination at $40^{\circ} \mathrm{C}$ and $42^{\circ} \mathrm{C}$, which imposes seed dormancy.

For all cultivars, the best germination speed was observed at $20^{\circ} \mathrm{C}$. Even though $25^{\circ} \mathrm{C}$ and $30^{\circ} \mathrm{C}$ were optimum temperatures for the germination of 'Everglades', germination rate was kept, which proved that this cultivar is thermotolerant.

Despite the reduction in germination rate at $35^{\circ} \mathrm{C}$, few days are necessary for the germination of 'Everglades' in comparison with other cultivars. Bertagnolli (2003) provides similar results with pelleted lettuce seeds, cv. 'Karla'.

High temperature decreased the vigor for all cultivars. Normal seedlings did not develop above $35^{\circ} \mathrm{C}$, according to Catão et al. (2014), who analyzed the effect of temperature on 'Everglades',
'Babá de Verão', 'Elisa', 'Luiza', 'Grand Rapids', 'Hortência', 'Salinas 88', and Rubete.

Changes in temperature during germination may result in accelerated process of plant deterioration, reducing seed quality; and it can also interfere with the quality of the end product, as in the case of lettuce leaves.

Deterioration is a process determined by a number of physiological, biochemical, physical and cytological processes, beginning at fertilization, in a progressive manner, in such way that decreases quality, and culminates in seed or plant death (MARCOS FILHO, 2015).

Seed germination led to the metabolism of different enzymes, which aimed at embryonic growth. These biochemistry markers can distinguish the changes in the cell membrane system. Esterase catalyzes the hydrolysis of several esters. These markers are widely distributed in multiple forms in plants. Allelic variations lead to different concentration, since intensity changes among different treatments.

In this study, esterase was the marker with the highest activity for 'Everglades', 'Grand Rapids' and 'Babá de Verão' at $42^{\circ} \mathrm{C}$, except for 'Elisa', with higher activity at $30^{\circ} \mathrm{C}$. However, low activity was identified for 'Everglades', at $20^{\circ} \mathrm{C}$; for 'Grand Rapids', at $25^{\circ} \mathrm{C}$; for 'Elisa', at $42^{\circ} \mathrm{C}$; and for 'Babá de Verão', at $30^{\circ} \mathrm{C}$ (Figure 1).

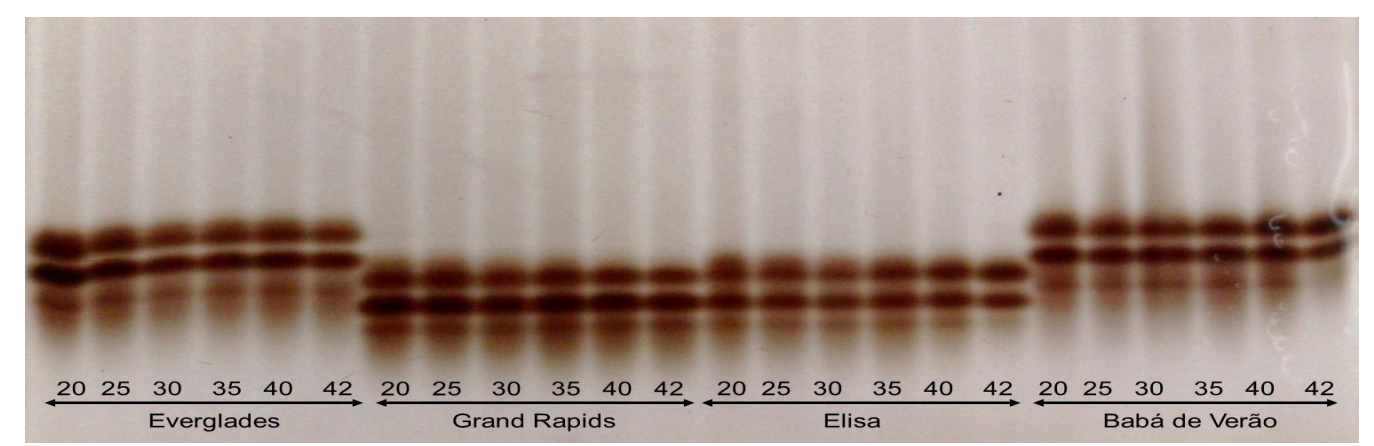

Figure 1. Profile of the esterase (EST) enzyme using lettuce seeds germinated under diferente temperatures $\left({ }^{\circ} \mathrm{C}\right)$.

Lipid peroxidation is a primary cause of seed membrane damage. Changes in esterase patterns indicate deteriorative events, which can contribute to the reduction of germination.

With the increase of temperature, esterase presented similar kinetics for 'Babá de Verão' and 'Everglades'. Similar behavior was reported for
'Grand Rapids' and 'Elisa'; however, the profiles for each cultivar pair were different.

'Everglades' seeds presented different behavior for catalase, i.e., they presented high activity at $20^{\circ} \mathrm{C}$, intermediate variation values from $25^{\circ} \mathrm{C}$ to $40^{\circ} \mathrm{C}$. This may be associated with the antioxidant action for thermotolerance events (Table 2). 
Table 2. Profile density (pixels) of enzyme alleles detected by the ImageJ software in enzyme gels for lettuce cultivars.

\begin{tabular}{|c|c|c|c|c|c|c|c|c|}
\hline \multirow{2}{*}{ Cultivars } & \multirow{2}{*}{$\begin{array}{c}\text { Enzymes } \\
\left({ }^{\circ} \mathrm{C}\right)\end{array}$} & \multicolumn{2}{|c|}{ EST } & \multirow{2}{*}{$\begin{array}{l}\text { CAT } \\
\text { Cat1 } \\
\end{array}$} & \multirow{2}{*}{$\begin{array}{l}\text { GOT } \\
\text { Gotl } \\
\end{array}$} & \multirow{2}{*}{$\begin{array}{l}\text { MDH } \\
d h l\end{array}$} & \multirow{2}{*}{$\begin{array}{l}\mathrm{ADH} \\
A d h l \\
\end{array}$} & \multirow{2}{*}{$\begin{array}{l}\text { PDC } \\
P d c 1\end{array}$} \\
\hline & & Est1 & Est2 & & & & & \\
\hline \multirow{6}{*}{ Everglades } & 20 & $46^{*}$ & $36^{*}$ & $109 * *$ & 41 & 126 & $197 * *$ & $198 * *$ \\
\hline & 25 & 55 & 38 & 62 & 40 & 118 & 170 & 30 \\
\hline & 30 & 66 & 49 & 78 & $46^{* *}$ & 125 & 177 & 21 \\
\hline & 35 & 58 & 47 & 62 & $35^{*}$ & $129 * *$ & 188 & 23 \\
\hline & 40 & 56 & 44 & $59 *$ & 38 & 125 & 174 & $18^{*}$ \\
\hline & 42 & $71 * *$ & $53 * *$ & 103 & 42 & $103 *$ & $164 *$ & 19 \\
\hline \multirow{6}{*}{$\begin{array}{l}\text { Grand } \\
\text { Rapids }\end{array}$} & 20 & 50 & 32 & $102 * *$ & $33 *$ & $68 *$ & $145^{*}$ & 24 \\
\hline & 25 & $49 *$ & $31 *$ & 91 & 42 & 85 & 159 & 31 \\
\hline & 30 & 55 & 32 & 74 & 51 & $97 * *$ & $164 * *$ & 23 \\
\hline & 35 & 53 & 26 & 75 & $52 * *$ & 79 & 154 & $26 * *$ \\
\hline & 40 & 55 & 32 & 59 & 42 & 94 & 157 & $20 *$ \\
\hline & 42 & $58 * *$ & $42 * *$ & $54 *$ & 50 & 87 & 162 & $20 *$ \\
\hline \multirow{6}{*}{ Elisa } & 20 & 67 & $44 *$ & 46 & $45^{*}$ & $129 * *$ & 184 & $15^{*}$ \\
\hline & 25 & 69 & 53 & $47 * *$ & 46 & 117 & $187 * *$ & 16 \\
\hline & 30 & $76 * *$ & 60 & 41 & 47 & 97 & 173 & $28 * *$ \\
\hline & 35 & 71 & 50 & 37 & 50 & 98 & 180 & 22 \\
\hline & 40 & 68 & 56 & 35 & 46 & 65 & 143 & 23 \\
\hline & 42 & $63 *$ & $60 * *$ & $33 *$ & $53 * *$ & $53 *$ & $135^{*}$ & 19 \\
\hline \multirow{6}{*}{$\begin{array}{l}\text { Babá de } \\
\text { Verão }\end{array}$} & 20 & 66 & 49 & 53 & 51 & 72 & 140 & 20 \\
\hline & 25 & 66 & 46 & $55^{* *}$ & $48 *$ & 66 & $134 *$ & 19 \\
\hline & 30 & $63^{*}$ & $44^{*}$ & 38 & 55 & $64 *$ & 137 & 20 \\
\hline & 35 & 67 & 50 & $36^{*}$ & $55^{* *}$ & 71 & 144 & $21 * *$ \\
\hline & 40 & 70 & 54 & 38 & 52 & 80 & $159 * *$ & $16^{*}$ \\
\hline & 42 & $86 * *$ & $74 * *$ & 41 & 50 & $101 * *$ & 146 & 18 \\
\hline
\end{tabular}

Est - Esterase (Est - Esterase); Cat - Catalase (Cat - Catalase); Got - Glutamate oxaloacetate transferase (Got - Glutamato oxaloacetato transferase); Mdh - malate dehydrogenase (Mdh - Malato desidrogenase); Adh - alcohol dehydrogenase (Adh - Álcool desidrogenase); Pdc - pyruvate decarboxylase (Pdc - Piruvato descarboxilase). * Alleles with lower density and ** alleles with higher density $(*$ alelos com menor densidade $\mathrm{e}^{* *}$ alelos com maior densidade).

Catalase-like activity was identified at $20^{\circ} \mathrm{C}$ and $25^{\circ} \mathrm{C}$ for all cultivars (Figure 2).

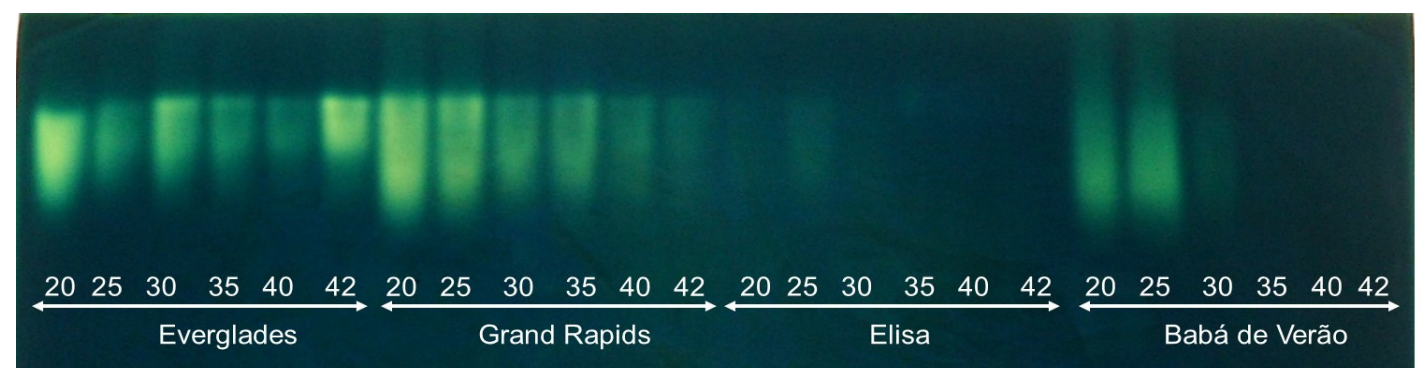

Figure 2. Profile of the catalase (CAT) enzyme using lettuce seeds germinated under different temperatures $\left({ }^{\circ} \mathrm{C}\right)$.

This enzyme catalyzes the decomposition of hydrogen peroxide $\left(\mathrm{H}_{2} \mathrm{O}_{2}\right)$. Catalase (CAT) and peroxidase are present in dry seeds. Thus, the reduction in the expression of this enzyme may result in the decrease in the prevention of oxidative damage. High temperatures during germination reduce the activity of CAT, mainly during photorespiration, and lead to the accumulation of oxidized glutathione (FOYER \& NOCTOR, 2003).

This event occurred for all lettuce seeds when using high temperatures during germination. Seed deterioration may be a consequence of cumulative membrane deterioration due to the increasing level of lipid peroxidation.

Seeds under high temperatures during germination decreased the activity of this enzyme, 
as in the case of cultivars 'Elisa' and 'Babá de Verão'. Since catalase acts as scavenger enzyme, i.e., peroxides remover, the lack of activity of this enzyme may be explained by the fact that seeds germinated outside their optimum temperature range, which could adversely have accumulated more peroxides during the embryo development, i.e., during germination.

Results observed in this study reinforce those of Nakada et al. (2010), who found increased lipid peroxidation with increased seed deterioration. Thus, reducing the activity of catalase (CAT) can make seed more sensitive to the effects of free radicals, and enhance the release of peroxide in the cells, with loss of seed viability.

For 'Everglades', 'Grand Rapids' and 'Babá de verão', the highest activity of glutamate oxalacetate transferase (GOT) occurred at temperatures from $30^{\circ} \mathrm{C}$ to $35^{\circ} \mathrm{C}$; for 'Elisa', the highest activity occurred at $42^{\circ} \mathrm{C}$ (Figure 3 ).

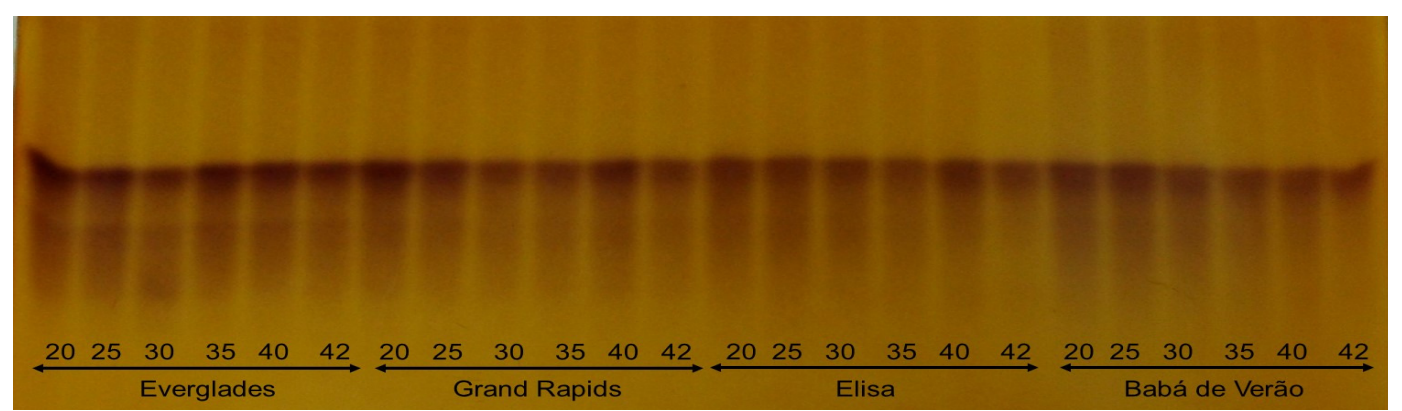

Figure 3. Profile of the glutamate oxalacetate transferase (GOT) enzyme using lettuce seeds germinated under different temperatures $\left({ }^{\circ} \mathrm{C}\right)$.

The increase in metabolic activity of seeds under highest temperature, with the increase in the temperature may lead to deterioration due to the increase in the expression of the enzyme glutamate oxaloacetate transferase, which is responsible for the oxidation of amino acids, reduction of $\alpha$ ketoglutarate for the synthesis of new amino acids, minimizing the energy supply for the Krebs cycle and to the developing embryo. Glutamate participates in the aminoacid metabolism. Furthermore, this enzyme is linked to nitrogen metabolism and protein synthesis during embryo growth recovery process (MALONE et al., 2007; PEDÓ, 2015), and is also involved in the respiratory process of seeds (MUNIZ et al., 2007). Since the activity of transaminases is stimulated under stress conditions, these enzymes may possibly be acting in the direction of deamination to provide amino acids, especially glutamine, for the common $\mathrm{N}$ pool. Therefore, it may be interpreted that the resulting amino acids were substrates for GOT and thus inducing enzyme activity for nitrate assimilation, translocation, and assimilation between the source and the sink (ASTHIR; TAK, 2017).

The highest activity of this enzyme occurs at temperatures between $20^{\circ} \mathrm{C}$ and $30^{\circ} \mathrm{C}$, which could be related to synthesis of amino acids on the metabolic pathway during germination.
Tunes et al. (2011) worked with two barley cultivars harvested in three seasons, and observed that seedlings showed no activity in cultivars harvested at 118 days after sowing (DAS). When harvest was carried out at 129 DAS, the enzyme was present only in 'Scarlett' cultivar. However, at 140 days, GOT was observed in both cultivars.

Due to the impact of several stress conditions, and to seed aging on the expression of antioxidant enzymes and gene activity, in recent years, these genetic and biochemical tools have been used as seed quality markers. However, there are some reports indicating that aging seeds under different temperatures affect the activities of enzymes not classified as antioxidant, such as $\beta$ amylase and malate dehydrogenase (TSANIKLIDIS et al., 2015).

Malate dehydrogenase (MDH) presented the highest activity for 'Everglades' at $35^{\circ} \mathrm{C}$; for 'Grand Rapids' at $30^{\circ} \mathrm{C}$; for 'Elisa' at $20^{\circ} \mathrm{C}$; and for 'Babá de Verão' at $42^{\circ} \mathrm{C}$ (Figure 4).

MDH catalyzes the oxaloacetate malate reaction of the Krebs cycle, and is responsible for providing energy to catalyze the conversion of triglycerides stored in glucose and other essential metabolites for germination (PÉDO, 2015). Therefore, this enzyme can act on metabolic processes, generating energy for seed germination. 


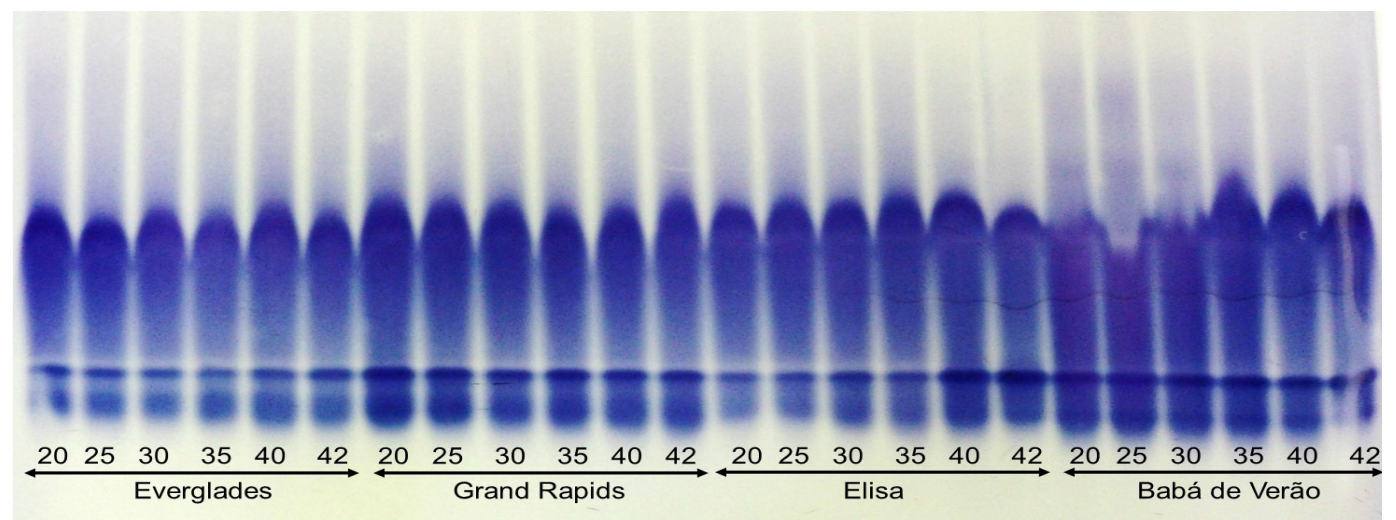

Figure 4. Profile of the Malate dehydrogenase (MDH) enzyme using lettuce seeds germinated under different temperatures $\left({ }^{\circ} \mathrm{C}\right)$.

In general, no changes were observed in $\mathrm{MDH}$, except for 'Babá de Verão'. Afterwards, higher activity occurred at $42^{\circ} \mathrm{C}$, which may have been due to increased respiration events.

Alcohol dehydrogenase (ADH) operates in the respiration process, by removing toxic substances from the seeds, such as acetaldehyde and ethanol, which are produced when cells begin the anaerobic activity. In the early stages of germination, starch degradation is carried out in almost all anaerobic process until seed coat is broken by the output of the embryonic axis.
The expression of $\mathrm{ADH}$ in seeds was quite pronounced, suggesting intense anaerobic respiration activity. Nevertheless, seedlings generally did not present activity (TUNIS et al., 2011). ADH activity increased for 'Everglades' at $20^{\circ} \mathrm{C}$; for 'Grand Rapids' at $30^{\circ} \mathrm{C}$; for 'Elisa' at $25^{\circ} \mathrm{C}$; and for 'Babá de Verão' at $40^{\circ} \mathrm{C}$.

In this work, the highest expression of $\mathrm{ADH}$ occurred for 'Babá de Verão', at temperatures from $40^{\circ} \mathrm{C}$ to $42^{\circ} \mathrm{C}$ (Figure 5).

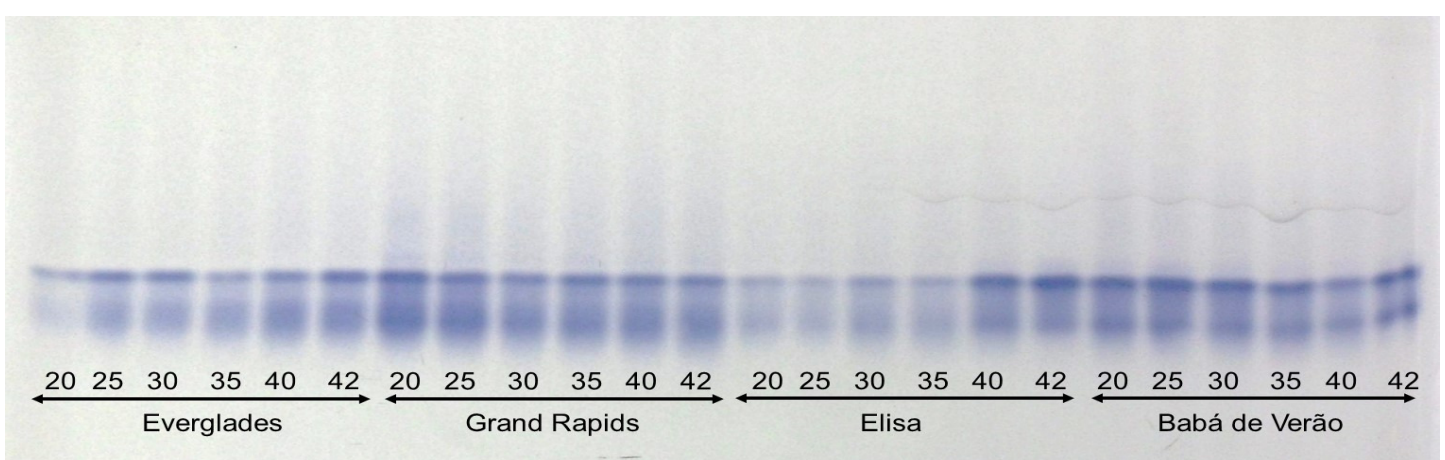

Figure 5. Profile of the Alcohol dehydrogenase (ADH) enzyme using lettuce seeds germinated under different temperatures $\left({ }^{\circ} \mathrm{C}\right)$.

By observing the results of germination at this temperature, seeds did not germinate since they are dormant. Thus, it can be inferred that seeds began to perform anaerobic respiration. Moreover, 'Grand Rapids' and 'Babá de Verão' showed intense activity at temperatures from $20^{\circ} \mathrm{C}$ to $30^{\circ} \mathrm{C}$. With oxidative stress, promoted with increasing temperature, free radicals are produced and the accumulation of toxic substances generated by oxidative processes. The events that comprise the seed deterioration process may cause excessive production of reactive oxygen species (ROS), and the overproduction of these functional groups is limiting for plant growth and development (CARVALHO et al., 2009).

However, the plants have a primary defense antioxidant enzyme system capable of eliminating ROS, such as the enzymes CAT. The balance between the excessive production of ROS and the ability to activate the antioxidant defense system will reflect on the ability of these seedlings to overcome the stress (BANDEIRA et al., 2014).

Increased activity for pyruvate decarboxylase (PDC) was found for 'Everglades' at $20^{\circ} \mathrm{C}$; for 'Grand Rapids' at $35^{\circ} \mathrm{C}$; for 'Elisa' at $25^{\circ} \mathrm{C}$; and for 'Babá de Verão' at $40^{\circ} \mathrm{C}$ (Figure 6). 


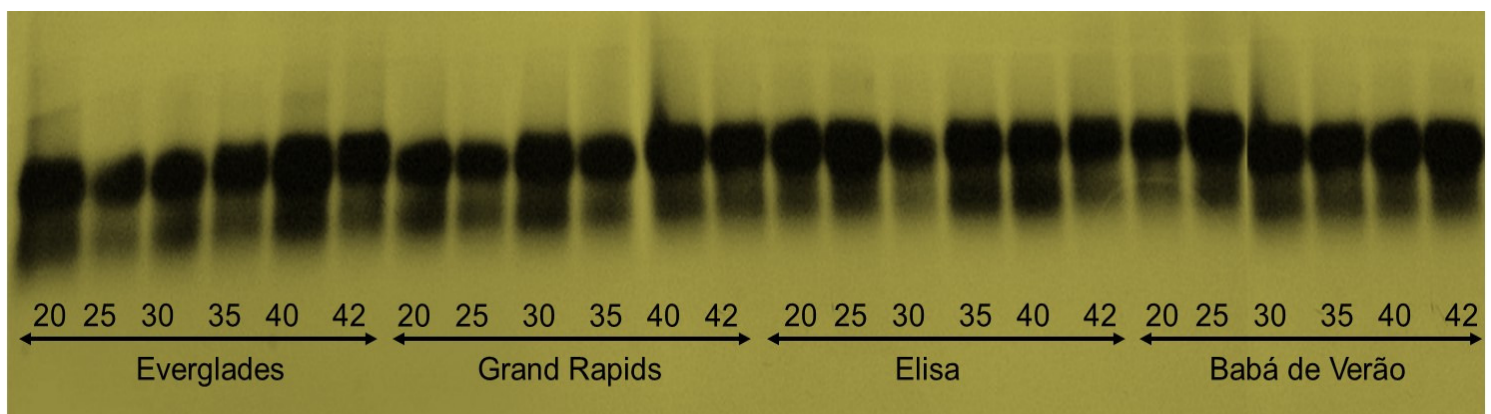

Figure 6. Profile of the pyruvate decarboxylase (PDC) enzyme using lettuce seeds germinated under different temperatures $\left({ }^{\circ} \mathrm{C}\right)$.

PDC participates in the anaerobic metabolism at the stage of glycolysis, when it acts as redactor agent, converting acetaldehyde reduced to ethanol by $\mathrm{ADH}$. This enzyme acts breaking the pyruvate present in the cytosol of cells that produce acetaldehyde.

This enzyme is a precursor of the alcohol dehydrogenase enzyme. Therefore, it is possible to observe direct relationship between the expression of these two enzymes.

\section{CONCLUSIONS}

At $35^{\circ} \mathrm{C}$, germination is limited for of 'Elisa', 'Grand Rapids' and 'Babá de Verão' lettuce cultivars, but not for 'Everglades', which presents germination above the commercial standard at this temperature, and is therefore considered thermotolerant.

'Everglades' is a potential genotype to be used in breeding programs aiming at selection of genotypes for regions of high temperature, such as the northeastern of Brazil.

Catalase can be used as enzyme-linked selection marker for thermotolerant lettuce seeds.

\section{ACKNOWLEDGEMENTS}

The authors thank the Coordination for the Improvement of Higher Education Personnel (CAPES) and the National Academic Cooperation Program (PROCAD) for the scholarship and financial support.

RESUMO: O objetivo deste estudo foi avaliar a qualidade fisiológica e bioquímica de sementes de alface por meio da germinação e expressão de enzimas a $20,25,30,35,40$ e $42^{\circ} \mathrm{C}$. As variáveis velocidade de germinação e o índice de velocidade de germinação foram estimadas. As expressões das enzimas alcool desidrogenase $(\mathrm{ADH})$, malato desidrogenase $(\mathrm{MDH})$, catalase $(\mathrm{CAT})$, esterase (EST), piruvate descarboxilase (PDC) e glutamato oxaloacetato transferase (GOT) foram avaliadas. Para análise dos genótipos foi empregado o delineamento inteiramente casualizado em esquema fatorial $4 \times 6$, testando quatro cultivares e seis diferentes temperaturas, com quatro repetições. A maior germinação e vigor foram observadas para a cv. 'Everglades' a $35^{\circ} \mathrm{C}$, o que prova que esta cultivar é termotolerante. A catalase pode ser considerada um marcador para a identificação de cultivares de alface termotolerantes. A cultivar 'Everglades' tem potential para uso em programas de melhoramento visando tolerância à alta temperatura durante a germinação.

PALAVRAS-CHAVE: Lactuca sativa L. Isoenzimas. Termotolerância. Esterase. Catalase. Álcool desidrogenase.

\section{REFERENCES}

ALFENAS, A. C. (Ed.). Eletroforese e marcadores bioquímicos em plantas e microrganismos. 2. ed. Viçosa: UFV, 627p., 2006.

ASTHIR, B.; TAK, Y. Fluoride-induced changes in carbon and nitrogen metabolism in two contrasting cultivars of Triticum aestivum L. Fluoride v. 50, n. 3, p. 334-342, 2017. 
BANDEIRA, J. M.; MARINI, P.; DE BORBA, I. C. G.; MARTINS, A. B. N.; DO AMARANTE, L.; \& DE MORAES, D. M. Metabolismo antioxidativo: uma ferramenta para detectar pequenas diferenças no vigor de sementes de soja. Iheringia. Série Botânica, v. 69, n. 2, p. 285-292, 2014.

BARBOSA, R. M.; COSTA, D. S.; SÁ, M. E. Envelhecimento acelerado em sementes de alface. Ciência Rural, v. 41, n. 11, p. 1899-1902, 2011. https://doi.org/10.1590/S0103-84782011005000138

BERTAGNOLLI, C. M.; MENEZES, N. L.; STORK, L.; SANTOS, O. S.; PASQUALLI, L. L. Desempenho de sementes nuas e peletizadas de alface (Lactuca sativa L.) submetidas a estresses hídrico e térmico. Revista Brasileira de Sementes, v. 25, n. 1, p. 7-13, 2003. https://doi.org/10.1590/S0101-31222003000100002

BRASIL. Ministério da Agricultura e Reforma Agrária. Regras para Análise de Sementes. Brasília: Departamento Nacional de Defesa Vegetal, 394p., 2009.

CARVALHO, C. A. D., LOURENÇO, M. V., BERTONI, B. W., FRANÇA, S. D. C., PEREIRA, P. S., FACHIN, A. L., PEREIRA, A. M. S. Antioxidant activity of Jacaranda decurrens Cham., Bignoniaceae. Revista Brasileira de Farmacognosia, 19(2B), 592-598, 2009. https://doi.org/10.1590/S0102695X2009000400015

CATÃO, H. C. R. M; GOMES, L. A. A.; SANTOS, H. O.; GUIMARÃES, R. M.; FONSECA, P. H. F.; CAIXETA, F. Aspectos fisiológicos e bioquímicos da germinação de sementes de alface em diferentes temperaturas. Pesquisa Agropecuária Brasileira, v. 49, n. 4, p. 316-322, 2014. https://doi.org/10.1590/S0100204X2014000400010

EDMOND, J. B.; DRAPALA, W. J. The effects of temperature, sand and soil, and acetone on germination of okra seed. Proceedings of the American Society for Horticutural Science, v.71, p. 428- 434, 1958.

FERREIRA, D. F. Sisvar: a computer statistical analysis system. Ciência e Agrotecnologia, v. 35, p. 1039-1042, 2011. https://doi.org/10.1590/S1413-70542011000600001

FOYER, C. H., NOCTOR, G. Redox sensing and signalling associated with reactive oxygen in chloroplast, peroxisomes and mitochondria. Physiologia Plantarum, v. 119, p. 355-364. 2003.

https://doi.org/10.1034/j.1399-3054.2003.00223.x

KIKUTI, A. L. P.; MARCOS FILHO, J. Seed vigour tests for lettuce seeds. Horticultura Brasileira, v. 30, n. 1, p. 44-50, 2012. https://doi.org/10.1590/S0102-05362012000100008

KOZAREWA, I., CANTLIFFE, D. J., NAGATA, R. T.; STOFFELLA, P. J. High maturation temperature of lettuce seeds during development increased ethylene production and germination at elevated temperatures.

Journal of the American Society of Horticultural Science, v. 31, n. 4, p. 564-570, 2006.

https://doi.org/10.21273/JASHS.131.4.564

MALONE, G.; ZIMMER, P. D.; MENEGHELLO, G. E.; CASTRO, M. A. S.; PESKE, S. T. Expressão diferencial de isoenzimas durante o processo de germinação de sementes de arroz em grandes profundidades de semeadura. Revista Brasileira de Sementes, v. 29, n. 1, p. 61-67, 2007. https://doi.org/10.1590/S010131222007000100009

MARCOS-FILHO, J. Fisiologia de sementes de plantas cultivadas. Londrina: Abrates, 2015. 659p.

MUNIZ, F. R.; CARDOSO, M. G.; PINHO, É. V. R. V.; VILELA, M. Qualidade fisiológica de sementes de milho, feijão, soja e alface na presença de extrato de tiririca. Revista Brasileira de Sementes, v. 29, n. 2, p. 195-204, 2007. https://doi.org/10.1590/S0101-31222007000200026 
NAKADA, P. G.; OLIVEIRA, J. A.; MELO, L. C.; SILVA, A. A.; SILVA, P. A.; PERINA, F. P. Desempenho durante o armazenamento de sementes de pepino submetidas a diferentes métodos de secagem. Revista Brasileira de Sementes, v. 32, n. 3, p. 42-51, 2010. https://doi.org/10.1590/S0101-31222010000300005

NASCIMENTO, W. M.; CRODA, M. D.; LOPES, A. C. A. Produção de sementes, qualidade fisiológica e identificação de genótipos de alface termotolerantes. Revista Brasileira de Sementes, v. 34, n. 3, p. 510-517, 2012. https://doi.org/10.1590/S0101-31222012000300020

NASCIMENTO, W. M.; CANTLIFFE, D. J.; HUBER, D. J. Ethylene evolution and endo-beta-mannanase activity during lettuce seed germination at high temperature. Scientia Agricola, v. 61, n. 2, p. 156-163, 2004. https://doi.org/10.1590/S0103-90162004000200006

NASCIMENTO, W. M. Preventing thermoinhibition in a thermosensitive lettuce genotype by seed imbibition al low temperature. Scientia Agricola, v. 60, n. 3, p. 477-480, 2003. https://doi.org/10.1590/S010390162003000300010

NASCIMENTO, W. M.; CANTLIFFE, D. J.; HUBER, D. J. Endo- $\beta$-mannanase activity and seed germination of thermosensitive and thermotolerance lettuce genotypes in response to seed priming. Seed Science Research, v. 11, n. 3 , p. $255-264,2001$.

PEDÓ, T.; MARTINAZZO, E. G.; AUMONDE, T. Z.; VILLELA, F. A. Desempenho de sementes, vigor e expressão isoenzimática em plântulas de teosinto (Euchlaena mexicana Schrader) sob efeito da restrição hídrica. Revista Brasileira de Biociências, v. 13, n. 1, p. 5-9, 2015.

RASBAND, W. S. ImageJ, U. S. National Institutes of Health, Bethesda, Maryland, USA, http://imagej.nih.gov/ij/, 1997-2016.

SUNG, Y.; CANTLIFFE, D. J.; NAGATA, R. T.; NASCIMENTO, W. M. Structural changes in lettuce seed during germination at high temperature altered by genotype, seed maturation temperature, and seed priming. Journal of the American Society for Horticultural Science, v. 133, n. 2, p. 300-311, 2008. https://doi.org/10.21273/JASHS.133.2.300

TSANIKLIDIS, G.; DERMITZAKI, E.; NIKOLOPOULOU, A. E.; DARAWSHEH, M. K.; AIVALAKIS, G. Cotton seed storage effects on vigour and activities of $\mathrm{NAD}^{+}$-dependent isocitrate dehydrogenase, malate dehydrogenase and $\beta$-amylase in seedlings. Seed Science and Technology, v. 43, n. 1, p. 111-120, 2015. https://doi.org/10.15258/sst.2015.43.1.12

TUNES, L. M.; BADINELLI, P. G.; BARROS, A. C. S. A.; MENEGHELLO, G. E.; AMARANTE, L. Influência dos diferentes períodos de colheita na expressão de isoenzimas em sementes de cevada. Revista Ceres, v. 58, n. 2, p. 178-184, 2011. https://doi.org/10.1590/S0034-737X2011000200008

ZUFFO, A. M. et al. Quality of pelleted and bare lettuce seeds at different temperatures. Australian Journal of Crop Science, v. 11, n. 3, p. 338, 2017. https://doi.org/10.21475/ajcs.17.11.03.pne352 